\title{
Evaluation of IPM module for management of giant African snail, Achatina fulica (Bowdich) in grape vine
}

\author{
S.D. PATIL* AND A.P. PADHYE
}

Agricultural Research Station, Niphad, NASIK (M.S) INDIA

\section{ARITCLE INFO}

Received : 18.08 .2015

Revised : 17.09 .2015

Accepted : 29.09 .2015

\section{KEY WORDS :}

Achatina fulica, Methomyl, Tobacco dust, Grape vine, Wheat straw, Jiggery, Yeast
*Corresponding author:

Email: saurushrutu@gmail.com

\begin{abstract}
Field experiment was conducted by the Agricultural Research Station, Niphad on farmer's field at Songaon, Tal. Niphad Dist. Nasik (M.S.) during Kharif 2008-09, 2009-10 and 2011-12 to assess the performance of IPM module against snails in grape vineyard in comparison to non IPM (farmer's practice). Result revealed that the IPM module comprising of various components viz., Clean cultivation i.e. cleaning and burning of waste pruned material, Removal of weeds from bunds and make it clean, Eliminate, all places where snails can hide, Collection and destruction of snails before sunrise and after sunset in solution of 5\% copper sulphate or lime solution, Collection and destruction of eggs laid by snails in field/garden near the root zone of the grape vine, Use of different traps as dry grass or waste material of vegetables heap or wetted gunny bags or old PVC pipe of 6 inch length at 20 to $25^{\prime}$ ' distance in field/garden during evening hrs., Use of poison bait of Methomyl $40 \mathrm{SP}$ : Wheat or rice bran or straw $50 \mathrm{~kg}+2$ per cent jaggery solution $+25 \mathrm{~g}$ yeast $+50 \mathrm{~g}$ Methomyl $40 \mathrm{SP} / \mathrm{ha}$. (Soaking wheat straw in water and 2 per cent jaggery solution and $25 \mathrm{~g}$ yeast and at the time of application mix $50 \mathrm{~g}$ methomyl 40SP. Application of this mixture in field/garden at various locations and near the bund by spreading during 15 days interval at 5 time or need based), Application of 5 per cent Metaldehyde @ $5 \mathrm{~kg} / \mathrm{ha}$ at two times at 15 to 20 days interval as need based application in field/garden at the time of evening, Application of tobacco dust around the field i.e. 5 feet from bund as $5 \mathrm{~cm}$ wide band in field/garden and also between two rows @ 50kg/ha at 3 times of 20 days interval afford excellent control of snails with higher yield (18.63 t/ha), monetary benefit (Rs. 327267/ha), net income (Rs. 230257/ha) and $\mathrm{B}: \mathrm{C}$ ratio (3.36).
\end{abstract}

How to view point the article : Patil, S.D. and Padhye, A.P. (2015). Evaluation of IPM module for management of giant African snail, Achatina fulica (Bowdich) in grape vine. Internat. J. Plant Protec., 8(2) : 389-392. 